\title{
LIFE HISTORY AND POPULATION BIOLOGY OF THE WHITE-CLAWED CRAYFISH, AUSTROPOTAMOBIUS PALLIPES PALLIPES, IN A BROOK FROM THE POITOU-CHARENTES REGION (FRANCE).
}

\author{
F. GRANDJEAN (1), B. CORNUAULT (1), S. ARCHAMBAULT (1), M. BRAMARD (2) \\ and G. OTREBSKY (3)
}

(1) Université de Poitiers, Laboratoire de Biologie Animale, UMR 6556, 40 avenue du Recteur Pineau, 86022 Poitiers Cedex, France.

(2) Délégation régionale du Conseil Supérieur de la Pêche du Poitou-Charentes, 112 faubourg de la Cueille, 86000 Poitiers, France.

(3) Conseil Supérieur de la Pêche, Fédération de Pêche de la Vienne, rue Guynemer, 86000 Poitiers, France.

\section{ABSTRACT}

A protected population of the white-clawed crayfish, Austropotamobius pallipes pallipes (Lereboullet), has been studied between 1995 and 1996. 1,511 crayfish were collected over the period of study including trap and hand catches. 356 animals exceeded the minimum legal size $-90 \mathrm{~mm}$ TL (Total Length)-, representing $23.6 \%$ of the total catches. Catch Per Unit Effort (C.P.U.E.) ranged from 1.2 in February to 8.6 in October. The sex ratio of total catch was biased in favour of females (1:1.9). Males are only dominant during the cold period where water temperature is less than $10^{\circ} \mathrm{C}$. Thelohania seems to be cyclic in this population with high levels of infected crayfish during both summers. No infected crayfish were found between January and March. Estimated densities ranged from 4.4 to 2.2 adults. $\mathrm{m}^{-2}$ of brook area. Mating activity started in mid to end November as day-length shortened and water temperature fell below $10^{\circ} \mathrm{C}$. Berried females ranged from 58.5 to $100.4 \mathrm{~mm}$ in TL. Mean pleopodal egg number declined over the duration of the incubation period (mean $=55$ eggs per female in December to 30 eggs per female in May). The maximum number of eggs was 85 for a female ( $85-\mathrm{mm} \mathrm{TL}$ ) captured in November. In the beginning of May, $40 \%$ of females sampled had no eggs. All the results seem to show an over-density of crayfish in this population and recommendations to regulate it are discussed.

Key-words : Austropotamobius pallipes pallipes, population biology, population dynamics, invertebrate fauna, pathology, density. 


\section{HISTOIRE DE VIE ET BIOLOGIE DES POPULATIONS DE L'ÉCREVISSE À PATTES BLANCHES, AUSTROPOTAMOBIUS PALLIPES PALLIPES, AU SEIN D'UN COURS D'EAU SITUÉ DANS LA RÉGION POITOU-CHARENTES (FRANCE).}

\section{RÉSUMÉ}

Une population protégée d'écrevisses à pattes blanches, Austropotamobius pallipes pallipes (Lereboullet), a été étudiée entre 1995 et 1996. 1511 écrevisses ont été collectées au cours de cette étude incluant des captures par nasse et à la main. 356 animaux excédaient la taille légale de capture $-90 \mathrm{~mm}$ LT (Longueur Totale)-, représentant $23,6 \%$ des captures. Les Captures Par Unité d'Effort (C.P.U.E.) sont comprises entre 1,2 en février et 8,6 en octobre. Le sex ratio sur les captures est biaisé en faveur des femelles $(1: 1,9)$. Les mâles sont dominants uniquement durant la période froide où la température de l'eau est inférieure à $10^{\circ} \mathrm{C}$. La thélohaniose semble apparaître de façon cyclique dans cette population avec de hauts taux d'écrevisses infestées au cours des étés 1995 et 1996. Aucune écrevisse infestée n'a été trouvée entre janvier et mars. Les densités estimées sont comprises entre 4,4 et 2,2 adultes au mètre carré. L'accouplement commence au milieu du mois de novembre où la durée du jour est courte et où la température de l'eau tombe en dessous de $10^{\circ} \mathrm{C}$. Les femelles grainées ont une taille comprise entre 58,5 et $100,4 \mathrm{~mm}$ de LT. La moyenne du nombre d'œufs pléopodaux baisse au cours de la période d'incubation (moyenne $=55$ œufs par femelle en décembre à 30 œufs en mai). Le maximum d'œufs est de 85 pour une femelle ( $85 \mathrm{~mm}$ de LT) capturée en novembre. Au cours du début du mois de mai, $40 \%$ des femelles échantillonnées ne portaient pas d'œuf. Tous ces résultats semblent montrer une surdensité d'écrevisses dans cette population, des recommandations pour la réguler sont discutées.

Mots-clés : Austropotamobius pallipes pallipes, biologie des populations, dynamique des populations, faune invertébrée, pathologie, densité.

\section{INTRODUCTION}

The white-clawed crayfish, Austropotamobius pallipes (LEREBOULLET, 1858) native to Western Europe, has become restricted in distribution over the past century due to a combination of factors including crayfish plague, over-fishing and habitat destruction (WESTMAN, 1985). This species occurs in oligotrophic or mesotrophic, neutral to alkaline streams over the most of its range, also in lakes and canals in Britain and Ireland (REYNOLDS, 1979 and 1982). In France, the species is still widespread, occurring in the major river systems (VIGNEUX et al., 1993). However, a recent survey performed by the National Fishing Authorities (Conseil Supérieur de la Pêche : C.S.P.) has revealed that the population number of the white-clawed crayfish has dramatically reduced over the past two decades (VIGNEUX et al., 1993). A. pallipes is listed as a protected species in Appendix III of the Bern convention 1982 and in Annexes II and V of the E.E.C. " Habitat and Species Directive " (1991), while it is considered an endangered species by the I.U.C.N. (GROOMBRIDGE, 1994). The threatened status of this species requires the establishment of suitable management strategies of wild populations, which cannot be performed without information on its life history.

Although crayfish are especially important in trophic dynamics of fresh water, particularly as macrophyte grazers (ABRAHAMSSON, 1966 ; MAGNUSSON et al., 1975) and detrital feeders (LORMAN and MAGNUSSON, 1978), field studies of biology and population dynamics are sparse in France (ARRIGNON and MAGNE, 1978 ; ARRIGNON and ROCHE, 1983 ; LAURENT and FOREST, 1979 ; ROQUEPLO, 1983). Recently, the C.S.P. has recognised the usefulness of genetic characterization of wild stocks in the 
management and conservation of $A$. pallipes and supported research on this topic. However, additional information on ecology and population dynamics is also useful to improve the efficiency of management. Most field studies have been made in British Isles and mainly in Ireland (O'KEEFFE, 1986 ; BREWIS and BOWLER, 1983 ; MATTHEWS and REYNOLDS, 1995).

This crayfish is relatively small, may reach a maximum body length of about $60 \mathrm{~mm} \mathrm{CL}$ (Carapace Length) or approximatively $120 \mathrm{~mm}$ total length. A. pallipes is a $\mathrm{K}$-selected species, long-lived, slow growing and iteroparous with relatively few eggs; among the largest and longest incubated (8-9 months) of any crustacean (BROWN and BOWLER, 1979 ; REYNOLDS, 1989). Several diseases occur in this species. According to REYNOLDS (1982), the most widespread disease found in wild populations was porcelain disease caused by the genus Thelohania (Sporozoa : Microsporidia). This genus is known from the U.S.A., mainland Europe and Britain. (UNESTAM, $1969 ; 1973 \mathrm{a}, \mathrm{b}$ ) and Russia (VORONIN, 1971). One species, T. contejeani, infects European crayfish, invading the muscle fibres and replacing them with masses of spores. This disease is chronic, leading to death 1 or 2 years after infection in Astacus astacus (SKURDAL et al., 1990).

One of the main data of these studies was to estimate the size of the population in the aim to consider efficient management of natural populations. The methods for estimating total number of animals in the population are based mainly on mark-recapture experiments. However to gain detailed estimates of population, it is necessary to capture large proportions of the populations. This parameter is very crucial to establish a plan of conservation for $A$. pallipes based on restocking attempts in brooks using wild animals. For this species, the main restocking experiments were made from mature individuals taken from the wild (GRANDJEAN et al., 1997 b). This is why restocking strategy requires estimation of population size of donor stocks as to avoid reducing their reproductive potential. An alternative strategy could be also consider to raise the natural range of this species based on the habitat restoration allowing to animals in over-density to recolonize naturally other locations. However, this strategy cannot be applied for all brooks as the Crochatière where in upstream from the crayfish population area, this brook runs through an agricultural area and in downstream it flows in a large river with water quality incompatible with the requirements of $A$. pallipes.

The objectives of this study were to define the life history of a wild French population where crayfish have been protected for five years, with the aim of determining if this population could safely provide animals for restocking.

\section{MATERIAL AND METHODS}

\section{Site description}

The Crochatière is located in the western part of.Poitou-Charentes region in France (Figure 1). This forested brook runs through:calcareous hillsides to flow into the Vienne. The natural slope is relatively high for this region (15\%). Well supplied by several rivers, the hydraulic regime is stable (constant supply of water). The water is well oxygenated and shows a good mineralization (63 $\mathrm{mg}$ of $\mathrm{Ca}^{++}$per liter). Water temperature showed a seasonal pattern (Figure 2). During summer, water temperature reached $14^{\circ} \mathrm{C}$ and fell to $2^{\circ} \mathrm{C}$ during winter. Aquatic macrophyte (Callitriche sp., Apium nodiflorum, Fontinalis antipyretica) are relatively abundant. The habitat is diversified with alternate pools and rifles areas. The stream varies from 10 to $80 \mathrm{~cm}$ in depth and 1 to $2 \mathrm{~m}$ in width. Flow rates and the granulometry are also varied. Stones and gravels are dominant whereas sand and clay are less well represented. The bank offers many hides with the presence of roots of ash and alder trees. The stream size is $7 \mathrm{~km}$ but the crayfish population takes place on $600 \mathrm{~m}$ : 


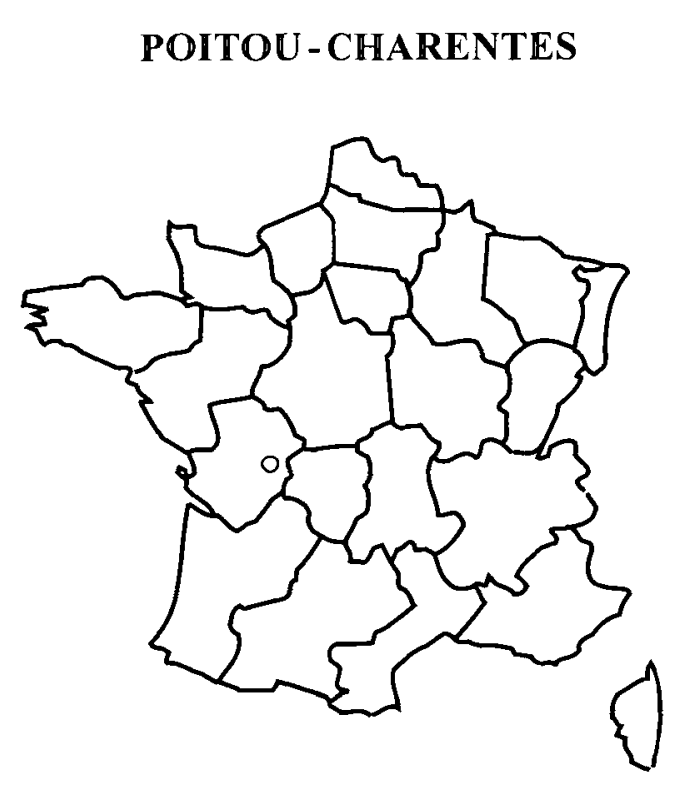

\section{RESEAUHYDROGRAPHIQUE}

DUDEPARTEMENT DE LA VIENNE
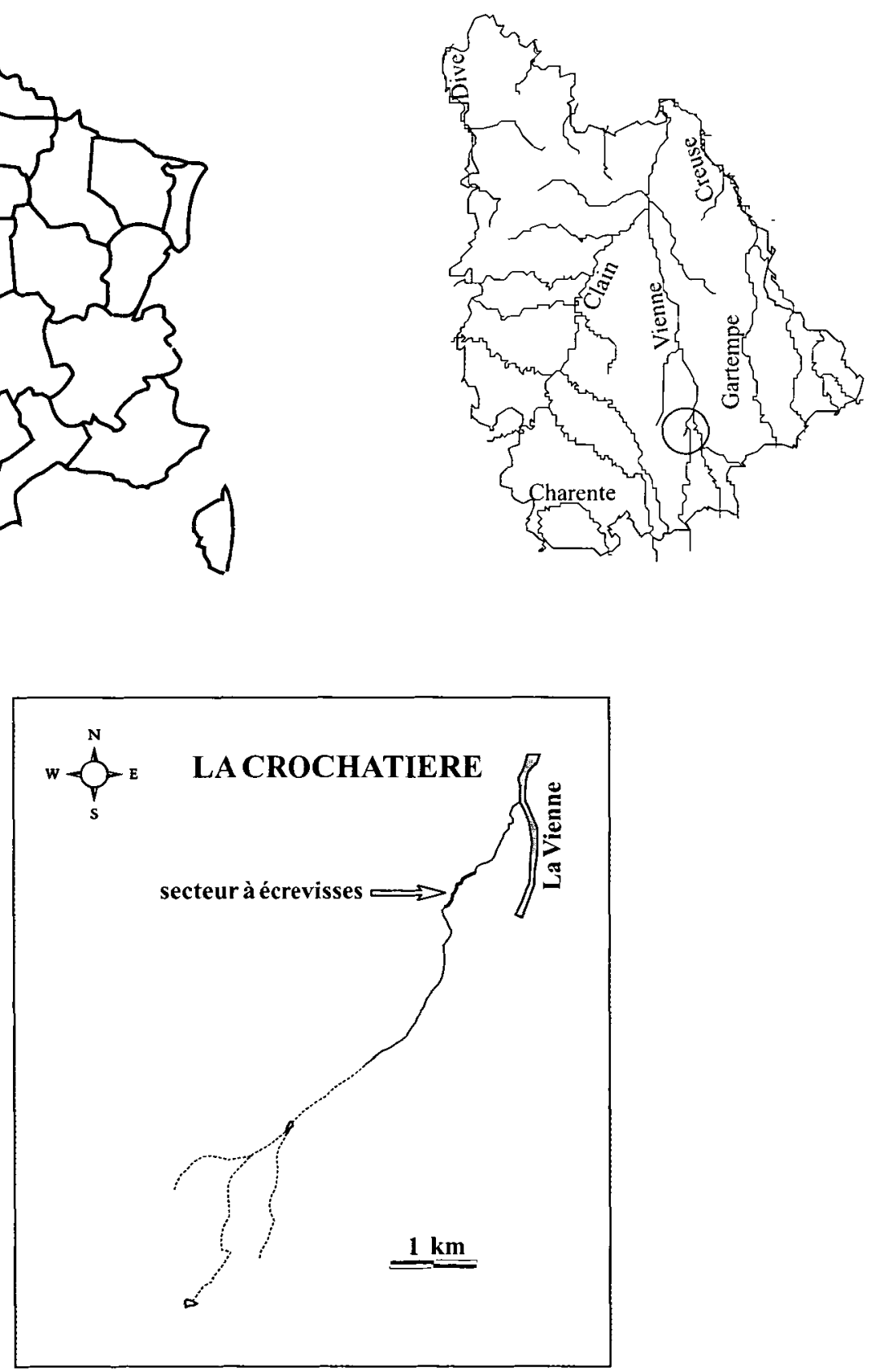

Figure 1

Map showing the Crochatière brook with the area harbouring the crayfish population.

Figure 1

Carte montrant le cours d'eau de la Crochatière et la localisation de la population d'écrevisses. 
A mixed fish population is present, mainly consisting of brown trout Salmo trutta fario (Linné) with a few other species such as Cottus gobio (Linné) and Phoxinus phoxinus (Linné) both in high density and some Noemacheilus barbatulus (Linné). A few species coming from the Vienne are sometimes observed such as Tinca tinca (Linné), Perca fluviatilis (Linné) and Barbus barbus (Linné). Eels are not present. The fishing of autochthonous crayfish is illegal throughout the Department, but within the Crochatière catching of fish is also prohibited.

\section{Field procedure}

The biological quality of the stream was investigated through samples of macroinvertebrates. Benthic invertebrates were collected by 8 replicate Surber samples (each of area $0.05 \mathrm{~m}^{2}$ ) in diameter (500 $\mu \mathrm{m}$ mesh net) (AFNOR, 1992). 8 samples were taken according to the protocol by VERNEAUX et al. (1983). Identification of invertebrates was done under a binocular dissecting microscope. The I.B.G.N. (Indice Biologique Global Normalisé) value is calculated according to the protocol of AFNOR (1992). The collected invertebrates reflect the biological water quality on a scale of 1 to 20 , where 1 indicates pollution and 20 no pollution. However, according to several authors (VERNEAUX et al., 1983), the I.B.G.N. value is naturally limited to 18 in headwater tributaries.

Sampling took place from 20 July 1995 to 02 August 1996. Crayfish were captured using 20 traps spaced at $10 \mathrm{~m}$ intervals. The traps are long and conical, the greatest diameter is $240 \mathrm{~mm}$ and the smallest $150 \mathrm{~mm}$. The traps are injection moulded in blue polyethylene plastic with mesh size of $14 \mathrm{~mm}$. Traps baited and set in the afternoon were retrieved the following morning after 15 hours. During the first four fishing operations performed to estimate population size (capture-recapture experiments), crayfish were also collected by hand to mark the largest additional number of crayfish. Catch Per Unit Effort (C.P.U.E.) was calculated only using animals captured by traps.

Animals were sexed in the field. Diagnostic of infected animals by Thelohania was made by visual observation. Total Length (TL) was measured to the nearest $1 \mathrm{~mm}$ using a micrometer (tip of rostrum to tip of telson). Most individuals were put back into the stream without those having porcelain disease caused by the microsporidian Thelohania.

\section{Population density}

Crayfish were marked during the first four fishings to perform a population estimate by mark-recapture method. Marking was performed by spots of different dark green nail varnish on the dorsal side of the carapace in the first three fishings. This marking did not seem to be toxic for animals. The colour used is closely related to those of crayfish carapace to avoid a bias in the capturability of marked animals.

Population size was estimated during summer (July-August 1995), in order to exclude mating and main moulting periods.

Following the example of O'KEEFFE (1986), the method by Schumacher and Eschmeyer was used. This is a modification of Schnabel's method (RICKER, 1975) which makes estimates from multiple mark and recapture samples, and has been used in many studies of crayfish populations (MASON, 1975 ; BROWN and BOWLER, 1977 ; DEMARS, 1979 ; SHIMIZU and GOLDMAN, 1983). In Schnabel's method (1938), the population estimate is calculated as :

$$
N=m_{t} c_{t} / r_{t} .
$$


The Schumacher and Eschmeyer modification is considered more accurate when there is a likehood of non-random mixing (RICKER, 1975), and was therefore preferred in this study. The inverse of $\mathrm{N}$ is calculated as :

$$
\frac{1}{N}=\frac{\sum r_{t} m_{t}}{\sum c_{t} m_{t}^{2}}
$$

$\mathrm{N}=$ estimate of population

$\mathrm{m}_{\mathrm{t}}=$ number marked

$c_{\mathrm{t}}=$ number examined for marks

$r_{1}=$ number recaptured marks

The variance of $1 / \mathrm{N}$ is computed by the equation :

$$
S^{2}=\frac{\sum\left(r_{t}^{2} / c_{t}\right)-\left(\sum r_{t} m_{t}\right)^{2} / \sum c_{t} m_{t}^{2}}{m-1}
$$

where $\mathrm{m}=$ the number of samples taken.

All methods of population estimation which employ mark and recapture techniques involve a number of basic assumptions :

(1) all marks last for the duration of the study ;

(2) marked crayfish are as likely to be caught as unmarked ones;

(3) marked crayfish become randomly mixed within the population ;

(4) marked and unmarked animals suffer the same mortality rates;

(5) there is no recruitment or movement of crayfish in or out of study area.

Each of the above assumptions seemed to be satisfactorily met in this study. Marks do not persist through one moult, thus this experiment was only performed during summer between the two main periods of moult in adult crayfish (first four fishings). However, some losses of marks by moult could have happened for males of $60-70 \mathrm{~mm}$ during this period. Only the adult crayfish were marked, thus juvenile recruitment was not taken into account. The recapture experiments were performed two weeks after marking to permit adequate dispersal within the brook. According to BROWN and BREWIS (1979), the estimate of the numbers of adult male $A$. pallipes based on trapped samples was 2.7 times lower than that derived from samples collected by hand. SEBER (1973) showed that the problem of different degrees of catchability may be overcome if different sampling methods are used. In the present case, two techniques of capture by traps and hand were used.

\section{Sexual maturity and fecundity}

Female maturity was determined from September to December by the presence of abdominal eggs and well-developed glair glands on the ventral surface of the abdomen. Fecundity was estimated by counting pleopodal eggs in berried females from immediately after spawning had taken place until May prior to hatching. 


\section{RESULTS}

\section{Biological quality}

Invertebrate abundance is summarised in Table I. The I.B.G.N. value is 15 on a scale of 1 to 20 .

\section{Table I}

List of macroinvertebrates from eight samples.

\section{Tableau I}

Liste des macroinvertébrés provenant de huit échantillons.

Surber samples

\begin{tabular}{|c|c|c|c|c|c|c|c|c|c|}
\hline & $n^{0} 1$ & $n^{\circ} 2$ & $n^{\circ} 3$ & $n^{\circ} 4$ & $n^{\circ} 5$ & $n^{\circ} 6$ & $n^{0} 7$ & $n^{\circ} 8$ & $\begin{array}{l}\text { Total } \\
\text { Number }\end{array}$ \\
\hline \multicolumn{10}{|l|}{ TRICHOPTERA } \\
\hline Glossosomatidae & & & 2 & & & & & & 2 \\
\hline Goeridae & 7 & & 12 & 15 & 4 & 2 & 5 & 8 & 53 \\
\hline Hydrospychidae & 4 & 20 & 1 & & & & & & 25 \\
\hline Limnephilidae & 1 & 1 & 1 & & 4 & & & & 7 \\
\hline Rhyacophilidae & 4 & 10 & 6 & & & & & & 20 \\
\hline Sericostomatidae & 1 & 5 & & 1 & 1 & & & & 8 \\
\hline \multicolumn{10}{|l|}{ EPHEMEROPTERA } \\
\hline Baetidae & 32 & 4 & 81 & 3 & 1 & 4 & 19 & 44 & 188 \\
\hline Ephemerellidae & 39 & 228 & 22 & 4 & 7 & 4 & 7 & 41 & 352 \\
\hline Ephemeridae & & & 3 & 10 & 4 & 13 & 4 & & 34 \\
\hline Heptageniidae & & & 11 & & & 1 & 3 & 8 & 23 \\
\hline $\begin{array}{l}\text { Leptophlebiidae } \\
\text { COLEOPTERA }\end{array}$ & & & & & 1 & & & 1 & 2 \\
\hline $\begin{array}{l}\text { Elmidae } \\
\text { DIPTERA }\end{array}$ & 92 & 250 & 67. & 24 & 8 & 9 & 73 & 12 & 535 \\
\hline DIPTERA & & & & & & & & & \\
\hline$\frac{\text { Chironomidae }}{\text { CRUSTACEA }}$ & 5 & 77 & 7 & 8 & 76 & 16 & 2 & 34 & 225 \\
\hline Gammaridae & 320 & 786 & 85 & 48 & 47 & 31 & 133 & 29 & 1479 \\
\hline MOLLUSCA & 81 & 27 & 46 & 120 & 101 & 151 & 228 & 21 & 774 \\
\hline ACHETA & & & 1 & & & & & & 1 \\
\hline OLIGOCHETA & 14 & 38 & 2 & 47 & 27 & 20 & 21 & & 169 \\
\hline Number of taxa & 29 & & & & & & & & \\
\hline Number of individuals & 3897 & & & & & & & & \\
\hline I.B.G.N. value & 15 & & & & & & & & \\
\hline
\end{tabular}

\section{Population structure}

The composition of crayfish catches from. July 1995:August 1996 is presented in Table II. Size frequiency histograms are illustrated in Figure $3 . \therefore 1,511$ crayfish were collected over the period of study inćluding trap and hand catches. 356 animals exceeded the minimum legal ${ }^{\prime}$ size of $90 \mathrm{~mm}$ TL (Total Length), representing $23.56 \%$ of the total catches. 


\section{Table II}

Catch data from the Crochatière (1995-96) (C.P.U.E. = Catch Per Unit Effort).

\section{Tableau II}

Captures sur la Crochatière (1995-96) (C.P.U.E. = Capture Par Unité d’Effort).

\begin{tabular}{|c|c|c|c|c|c|c|c|c|c|}
\hline \multirow{2}{*}{$\begin{array}{c}\text { Trip } \\
\text { No }\end{array}$} & \multirow[t]{2}{*}{ Date } & \multirow{2}{*}{$\begin{array}{l}\text { Number } \\
\text { of traps }\end{array}$} & \multicolumn{3}{|c|}{ Trapped animals } & \multirow[t]{2}{*}{ C.P.U.E. } & \multirow{2}{*}{$\begin{array}{l}\text { Captured } \\
\text { animals }\end{array}$} & \multirow{2}{*}{$\begin{array}{l}\text { Infected } \\
\text { animals }\end{array}$} & \multirow{2}{*}{$\begin{array}{l}\text { Sex } \\
\text { ratio }\end{array}$} \\
\hline & & & Male & Female & Total & & & & \\
\hline $1^{*}$ & $02 / 07 / 95$ & 20 & 42 & 66 & 108 & 5.4 & 233 & 30 & 0.39 \\
\hline $2^{\star}$ & $20 / 07 / 95$ & 20 & 40 & 76 & 116 & 5.8 & 229 & 30 & 0.32 \\
\hline $3^{*}$ & $02 / 08 / 95$ & 20 & 36 & 84 & 120 & 6 & 265 & 10 & 0.29 \\
\hline $4^{\star}$ & $02 / 09 / 95$ & 20 & 38 & 96 & 134 & 6.7 & 192 & 5 & 0.26 \\
\hline 5 & $03 / 10 / 95$ & 20 & 65 & 108 & 173 & 8.65 & 173 & 7 & 0.37 \\
\hline 6 & $20 / 11 / 95$ & 20 & 54 & 48 & 90 & 4.5 & 90 & 6 & 0.60 \\
\hline 7 & $14 / 12 / 95$ & 20 & 18 & 11 & 29 & 1.45 & 29 & 5 & 0.81 \\
\hline 8 & $01 / 02 / 96$ & 20 & 18 & 6 & 24 & 1.2 & 24 & 0 & 0.75 \\
\hline 9 & $21 / 03 / 96$ & 20 & 29 & 19 & 48 & 2.4 & 48 & 0 & 0.60 \\
\hline 10 & $02 / 05 / 96$ & 20 & 34 & 27 & 61 & 3.05 & 61 & 2 & 0.56 \\
\hline 11 & $29 / 05 / 96$ & 19 & 30 & 40 & 70 & 3.68 & 70 & 5 & 0.41 \\
\hline 12 & $02 / 08 / 96$ & 19 & 23 & 74 & 97 & 5.1 & 97 & 13 & 0.23 \\
\hline
\end{tabular}

* additional hand collections.

The sex ratio of the total catch was 426 males:821 females with males dominating the largest size-classes in particular. Males are dominant during the cold period where water temperature is less than $10^{\circ} \mathrm{C}$ and females during May to October where water temperature exceeds $10^{\circ} \mathrm{C}$. The largest male and female crayfish caught were $110 \mathrm{~mm}$ and $115 \mathrm{~mm}$ respectively.

The C.P.U.E. varied considerably between the seasons, as illustrated in Table II and Figure 2. The largest numbers of animals were obtained during summer when the water temperature was higher $\left(14^{\circ} \mathrm{C}\right)$. During autumn and winter, the number of captured animals decreased with the lowest value in February when the water temperature was the coldest $\left(2^{\circ} \mathrm{C}\right)$. This may reflect decreased activity of crayfish. Then, with the increase in water temperature, the C.P.U.E. gradually increased until August 1996.

\section{Pathology}

Crayfish infected by Thelohania were found in high numbers in the first four fishings (July and August 1995) with $12.9 \%, 13.1 \%, 3.8 \%$ and $2.6 \%$ respectively. The infected animals have been diagnosed by visual observations. So these rates of infection were probably underestimated. All infected individuals were killed. This disease appeared in catches during summer when the water temperature was the warmest. It was not seen between January and March, corresponding to the period of the lowest water temperatures.

The disease seems to be cyclic in this population, as a high percentage (13.4\%) of infected animals was again collected in August 1996. 

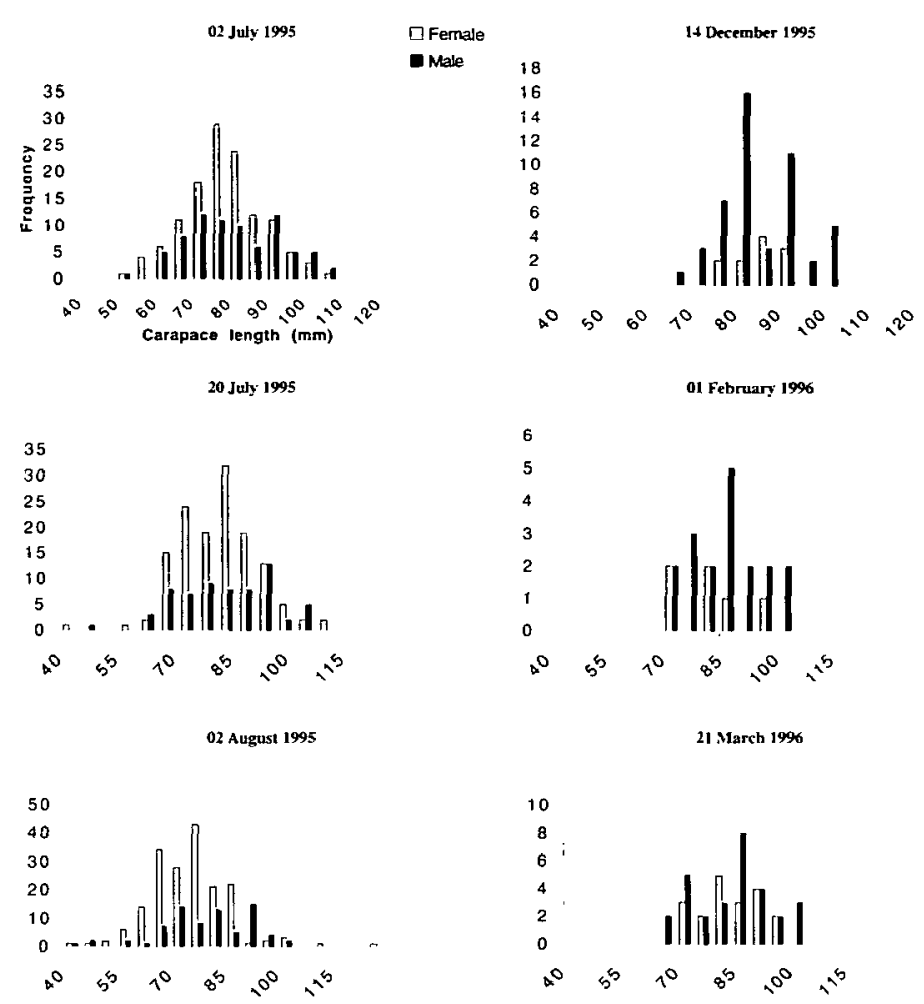

02 September 1995
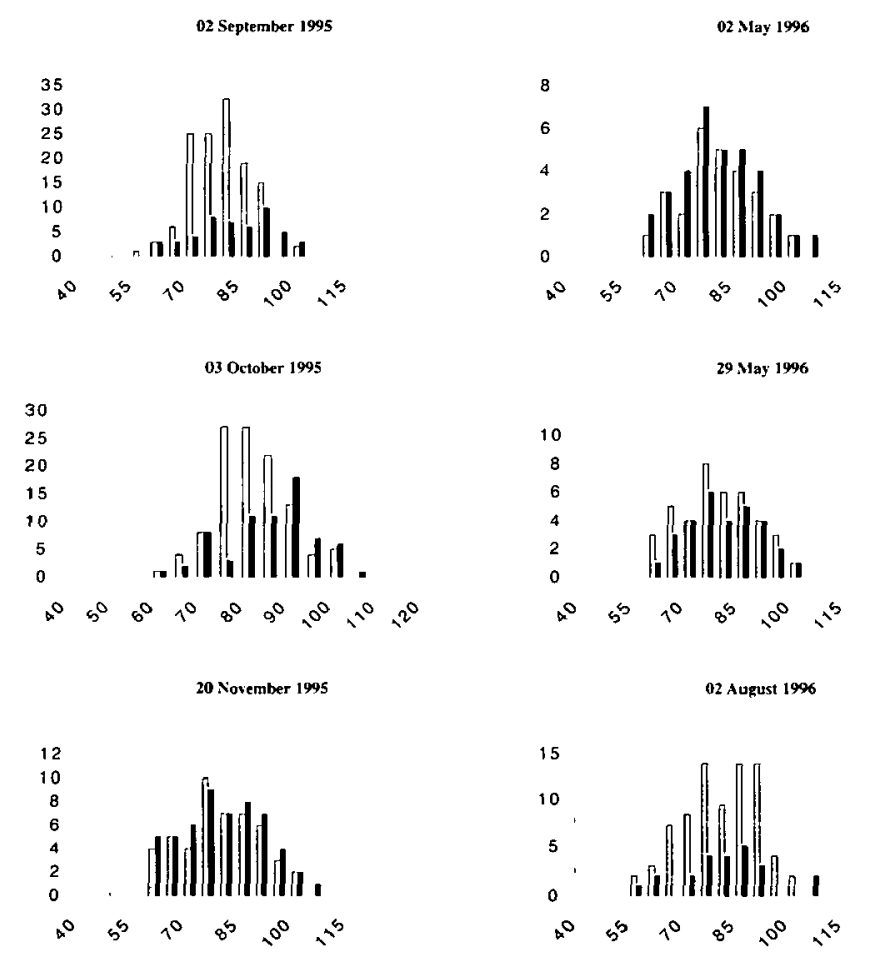

Figure 3

Size frequency histograms of crayfish captured each fishing between 1995-96.

Figure 3

Histogrammes des fréquences de taille des écrevisses capturées au cours de chaque opération de pêche entre 1995-96. 


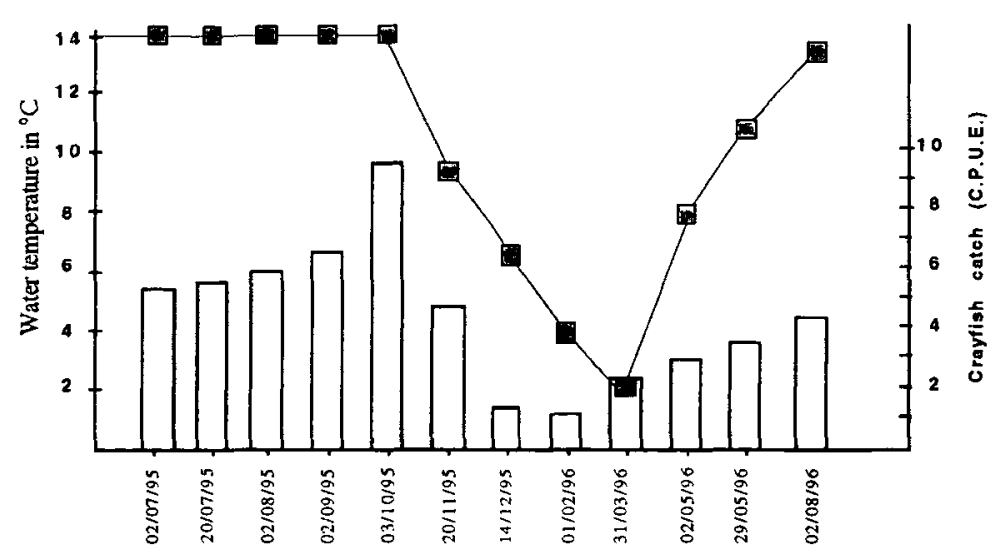

Figure 2

C.P.U.E. (Catch Per Unit Effort) expressed in taking account only animals captured by traps and water temperature graph.

Figure 2

C.P.U.E. (Capture Par Unité d'Effort) exprimée en prenant en compte uniquement les écrevisses capturées par nasse et courbe de température de l'eau.

\section{Population density}

Estimate of the size of the Crochatière adult population was $1,000 \pm 334 \mathrm{SD}$ (Table III). Estimated densities ranged from 2.2 to 4.4 mature adults. $\mathrm{m}^{-2}$ of brook area. When the population is subdivided into animals less than, and larger than $90 \mathrm{~mm} \mathrm{TL}$, equivalent to the minimum size for legal capture of crayfish in France (LAURENT and FOREST, 1979), estimates of individuals larger than $90 \mathrm{~mm}$ TL ranged from 133 to 419 . Recapture rates were high, approximatively $44.5 \%$ overall.

\section{Table III}

Trap recapture of marked adult crayfish (July-August 1995) $\left(m_{1}=\right.$ sum of number marked ; $c_{1}=$ catch size ; $r_{t}=$ sum of number recaptured marks).

\section{Tableau III}

Recapture des écrevisses marquées (juillet-août 1995) $\left(m_{t}=\right.$ somme des écrevisses marquées ; $c_{t}=$ nombre total d'écrevisses capturées $; r_{t}=$ somme des écrevisses marquées recapturées).

\begin{tabular}{cclclll}
\hline Trip No & Days & ct & Marked crayfish & mt & rt & ct $^{\star} \mathbf{m t}$ \\
\hline 1 & 0 & 233 & 202 & 0 & 0 & 0 \\
2 & & 229 & 199 & 202 & 63 & 46258 \\
3 & & 265 & 255 & 401 & 103 & 106265 \\
4 & & 192 & 0 & 656 & 126 & 125952 \\
Total & & & & 292 & 278475 \\
\hline
\end{tabular}




\section{Reproduction period, maturity size and fecundity}

Mating activity started in mid to late November as the day-length shortened and water temperatures fell below $10^{\circ} \mathrm{C}$. On 20 November, at $8^{\circ} \mathrm{C}$ water temperature, 7 females carrying spermatophores were taken in a catch of 48 mature females indicating that the mating had recently begun. In December, of 10 mature females, 7 had spawned and 1 had mated. Berried females ranged from 58.5 to $100.4 \mathrm{~mm}$ in TL. The maximum number of eggs was 85 for a female $(85 \mathrm{~mm}$ TL) captured in November. Mean pleopodal egg number declined over the duration of the incubation period. Mean pleopodal fecundity was estimated in four occasions between December to May.

Mean monthly fecundity estimates decreased from 55 eggs per female in December to 30 eggs per female in May. In May, $40 \%$ of females sampled had no eggs. It seems that large females ( $90 \mathrm{~mm} \mathrm{TL}$ ) lose their eggs more easily than small females.

\section{DISCUSSION}

\section{Water quality}

Estimated water quality (I.B.G.N. value $=15$ ) is relatively good but not optimal. Indeed, the absence of invertebrates of indicator groups 8-9 such as Plecoptera and several families of Trichoptera explains this relatively low value found for a brook harbouring the white-clawed crayfish. BRAMARD et al. (1996) reported I.B.G.N values of 18 and 19 in the two brooks harbouring $A$. pallipes which seemed to have chemical and physical characteristics very close from those of the Crochatière (similar distance of the crayfish population from the spring around $1.5 \mathrm{~km}$, mineralization, geological and morphological criteria). So, it seems that the limiting factor explaining the absence of Plecoptera and Trichoptera is not related to the slope of the brook but to its organic and physical alteration. This brook passes through an agricultural area which could have a negative influence on the water quality, explaining the large number of Oligocheta and Chironomus species in this brook. Moreover, in 1994, the brook was cleaned and dredged, which resulted in an increase in sedimentation which could have had a negative impact on these macroinvertebrates. All these perturbations resulting from human activities could be problematic for the durability of this population.

\section{Infrastructure}

The sex ratio of adult crayfish in trap catches has a seasonal pattern. The bias in the sex ratio in winter (male predominance) and summer (female predominance) trapping is due to a difference in activity between the sexes. Several studies have shown that egg-bearing females are especially less active than both other females without eggs and males (MATTHEWS and REYNOLDS, 1995) and thus were difficult to collect by traps. For these reasons, the percentage of berried females estimated in the population is probably an underestimation during the period of spawning.

C.P.U.E. values were highest in October, coinciding with high activity among the crayfish, which were at the height of their mating season. At this period, the sex ratio was near 1:1. These results agree with those in other European studies (MATTHEWS and REYNOLDS, 1995). However, the C.P.U.E. values were also high during summer, confirming that it was a suitable period to perform density estimates. 


\section{Pathology}

Our results have shown a high rate of infection by Thelohania in this population. Moreover, the diagnostic of this disease was performed simply by visual observation entailing probably an underestimate of that. The occurrence of porcelain disease has been variously estimated in other studies. ROQUEPLO (1983) found a level of infected animals ranged from $1.8 \%$ to $3 \%$ in three brooks in the South-West of France. A similar rate has been found in a Corsican brook (ARRIGNON and MAGNE, 1978). VEY and VAGO (1973) noted that $10 \%$ of animals were infected in a brook of Lozère. A summer level of $30 \%$ infection was noted in streams near Limoges (REYNOLDS, 1979, unpublished). In other European countries, the levels of infected animals vary highly and ranged from $0.73 \%$ in an Irish lake (O'KEEFFE and REYNOLDS, 1983) to $30 \%$ in Germany (SCHAPERCLAUSS, 1954). In the Crochatière, the levels of infection seem to fluctuate considerably during the year with no infected animals in February to March, whereas $17 \%$ were observed a few months later in summer. This result could be explained by the fact that all infected animals collected during fishing operations are killed and by a reduced activity of infected animals during the cold period compared with those of uninfected individuals. Several studies have confirmed that this disease may influence the likehood of crayfish entering traps (UNESTAM, $1973 \mathrm{~b}$; O'KEEFFE and REYNOLDS, 1983). Thus, the fact that during winter, fishing operations were only made from traps without hand sampling, the estimated percentage of infection may be more underestimated during the cold periods than warm ones. According to BROWN and BOWLER (1977) the disease is density-dependent, which could suggest that infection may persist at a low and stable level for a period of years but could, under certain conditions during over-density period, reach relatively high levels and thereby bring about a population crash. The high level of infected crayfish seems to indicate that a high density of crayfish is probably present in the Crochatière, which could induce soon its crash.

\section{Density}

In this study, density ranged from 4.6 to 2 animals per square metre for mature animals. In regard to results estimated from other studies, it seems that there exists in the Crochatière a high density of crayfish larger than $60 \mathrm{~mm}$ TL. DEMARS (1979) estimated the density of $A$. pallipes of TL larger than $30 \mathrm{~mm}$ to be 2.5 per square metre in a stream in the head water of the river Loire (France). In a Corsican stream, the density of crayfish larger than $50 \mathrm{~mm}$ TL was estimated at 4.0 per square metre (ARRIGNON and ROCHE, 1983). TROSCHEL (1997) found 1.4 crayfish per square metre with animals ranging to $10 \mathrm{~mm}$ to $90 \mathrm{~mm}$ TL in a German brook. RALLO and GARCIA-ARBERAS (1999) made an estimate of 1.7 crayfish per square metre in a Basque brook. The relatively high density revealed in our study could explain both the high percentage of animals infected by Thelohania and the low fecundity of females. It was also important to note that a high percentage of crayfish at legal size for capture (23.6\%) has been found in this population, which might suggest firstly that no illegal fishing has been performed and secondly that this brook has suitable biotic and abiotic characteristics for good growth of crayfish.

\section{Maturity size and fecundity}

The knowledge of fecundity is a prerequite for understanding the dynamics and the production of populations. RHODES and HOLDICH (1982) investigated the relationship between size and the number of pleopodal eggs produced by crayfish from two sites in English midlands and recorded the number of ovarian eggs on a small sample. Most studies have shown a positive correlation between the size of the females and the number of pleopodal eggs in crayfish (ABRAHAMSSON, $1971 ; 1972$ ) and in A. pallipes particularly (RHODES and HOLDICH, 1982). However, larger females showed a wide range in eggs 
size and numbers (MASON, 1979 ; CARRAL et al., 1993). Thus the correlation coefficients estimated from regressions of egg number against size in $A$. pallipes ranged from 0.51 to 0.93 (in REYNOLDS et al., 1992). The maximum number of pleopodal eggs (165) was found attached to a female of $90 \mathrm{~mm}$ TL (REYNOLDS et al., 1992). However, ABRAHAMSSON (1966) and MORRISSY (1970) found that food availability and population density influence reproductive potential of freshwater crayfish. Thus, a low fertility of females could be induced by a high population density. More recently, MOMOT et al. (1978) produced clear evidence that reproduction and subsequent population recruitment is density-dependent in lake populations of the crayfish Orconectes virilis. With regard to pleopodal egg numbers, our results showed relatively poor egg production for all females and for larger females in particular. These results could suggest that a high density of crayfish exists in this population, and are in agreement with the high proportion of individuals infected by Thelohania. During the long incubation period, we observed a high decrease in number of pleopodal eggs. Post-spawning eggs losses of $50 \%$ have been estimated. However, the low egg production and the decline of incubated egg number could be also explained through the insidious alterations of water quality revealed by the absence of Plecoptera and several families of Trichoptera in the I.B.G.N. analysis. In Astacus astacus, CUZERKIS (1988) has shown that the oxygen rate had a negative effect of egg production. Other explanations are possible through infection, most commonly with Saprolegnia and other fungi or related to the fact that the egg pedicel thins progressively during incubation (STREMPEL, 1973) or disturbance, for example through by frequent contact between specimens due to over-density. These results agree with those obtained by several authors (O'KEEFFE, 1986 in particular). In relation to reproductive success and choice of animals for restocking purposes, it'seems that very large females have a lower number of eggs than expected. This result confirms the data obtained by O'KEEFFE (1986) and suggests that large females should'not be used for restocking purposes. The best reproductive success is shown for females of $70 \mathrm{~mm}$ TL (O'KEEFFE, 1986).

The onset of size at sexual maturity in females, estimated from the presence of welldeveloped cement glands, was approximatively of $58 \mathrm{~mm}$ TL. This size was larger than these found by GRANDJEAN et al. (1997 a, b) in streams located in the same region with approximatively $52 \mathrm{~mm}$ and $56 \mathrm{~mm}$ TL for females and males respectively. This difference is probably due to the use of a different method for characterizing the onset of sexual maturity (allometric growth in GRANDJEAN et al, $1997 \mathrm{a}, \mathrm{b}$ ). It could also be explained by a larger size increment during the moult for animals from the Crochatière, or by a larger number of moults within the juvenile stage.

\section{CONCLUSION}

If the protection of habitat is a prerequite for the preservation of the white-clawed crayfish by establishment of reserve areas, our study has shown that a conservation plan should include also suitable management of the protected populations. The monitoring of population could help to prevent natural population crashes due to an over-density and also indicate populations which could serve to give animals for restocking without going down their reproductive potential or even to restore legal fishing. However, an alternative strategy based on the restoration of habitat could allow to specimens living in over-density to go to recolonize naturally other sites. LAURENT and SUSCILLON (1962) reported that the successful of many restocking attempts were often uncertain. According to them, it seems that natural recolonization should be more suitable than restocking. However, for the Crochatière, it seems that this strategy could not be applied due to the fact that this brook has no tributary and flows directly through the main river of the hydrographic basin with a water quality which can be improved in acceptable manner for A. pallipes. 


\section{REFERENCES}

ABRAHAMSSON S.A.A., 1966. Dynamics of an isolated population of the crayfish Astacus astacus Linné. Oikos, 17, 96-107.

ABRAHAMSSON S.A.A., 1971. Density, growth and reproduction in populations of Astacus astacus and Pacifastacus leniusculus in an isolated pond. Oikos, 22, 373-380.

ABRAHAMSSON S.A.A., 1972. Fecundity and growth of some populations of Astacus astacus (Linné) in Sweden with special regard to introductions in northern Sweden. Report of the Institute for Freshwater Research, Drottningholm, 52, 23-37.

AFNOR, 1992. Détermination de l'indice biologique global normalisé (I.B.G.N.), 9 p.

ARRIGNON J.C., MAGNE P., 1978. Population d'écrevisses (Atlanto-Astacus pallipes pallipes (Lereboullet) d'un ruisseau de Lozère, France. Freshwater Crayfish, 4, $131-140$.

ARRIGNON J.C., ROCHE B., 1983. Population of the crayfish Austropotamobius pallipes pallipes (Lereboullet) in a brook of Corsica (France). Freshwater Crayfish, 5, 229-238.

BRAMARD M., BACHELIER E., OTREBSKY G., RAMBEAU J., ROUVEREAU C., GRANDJEAN F., 1996. Répartition des écrevisses à pattes blanches en PoitouCharentes. Rapport interne, Conseil Supérieur de la Pêche, Délégation Régionale du Poitou-Charentes (France), $61 \mathrm{p}$.

BREWIS J.M., BOWLER K., 1983. A study of the dynamics of a natural population of the freshwater crayfish, Austropotamobius pallipes. Freshwater Biology, 13, 443-452.

BROWN D.J., BOWLER K., 1977. A population study of the British freshwater crayfish Austropotamobius pallipes (Lereboullet). Freshwater Crayfish, 3, 33-49.

BROWN D.J., BOWLER K., 1979. The relationship between size and age throughout the life cycle in Austropotamobius pallipes. Institut National de la Recherche Agronomique, Thonon-les-Bains, 35-42.

BROWN D.J., BREWIS J.M., 1979. A critical look at trapping as a method of sampling a population of Austropotamobius pallipes (Lereboullet) in a mark and recapture study. Freshwater Crayfish, 4, 159-164.

CARRAL J.M., CELADA J.D., GONZALEZ J., SAEZ-ROYUELA M., GAUDIOSO V.R., 1993. Mating and spawning of freshwater crayfish Austropotamobius pallipes (Lereboullet) under laboratory conditions. Aquaculture and Fisheries Management, $25,721-727$.

CUZERKIS J.M., 1988. Astacus astacus in Europe. In Freshwater Crayfish - Biology, Management and Exploitation, HOLDICH D.M., LOWERY R.S. (eds), 309-340, Croom Helm, London.

DEMARS J.J., 1979. Premières données sur les populations d'écrevisses de quelques cours d'eau du haut bassin Loire-Allier. Freshwater Crayfish, 4, 165-174.

GRANDJEAN F., ROMAIN D., AVILA-ZARZA C., BRAMARD M., SOUTY-GROSSET C., MOCQUARD J.P., 1997 a. Size at maturity and sexual size dimorphism of the white-clawed crayfish Austropotamobius pallipes pallipes (Lereboullet) from a wild French population (Deux-Sèvres). Crustaceana, 70 (1), 31-44.

GRANDJEAN F., ROMAIN D., SOUTY-GROSSET C., MOCQUARD J.P., 1997 b. Size at sexual maturity and morphometric variability in three populations of Austropotamobius pallipes pallipes (Lereboullet, 1858) according to a restocking strategy. Crustaceana, 70 (4), 454-468.

GROOMBRIDGE B., 1994. IUCN Red list of threatened animals. IUCN, Gland Switzerland and Cambridge, U.K., 286 p. 
LAURENT P.J., FOREST J., 1979. Données sur les écrevisses qu'on peut rencontrer en France. Astacus astacus, Procambarus clarkii, Astacus leptodactylus, Austropotamobius pallipes. Pisciculture Française, 56, 25-40.

LAURENT P.J., SUSCILLON M., 1962. Les écrevisses en France. Annales de la Station Centrale d'Hydrobiologie, 9, 336-395.

LEREBOULLET A., 1858. Description de deux nouvelles espèces d'écrevisses de nos rivières. Mémoires de la Société des Sciences Naturelles de Strasbourg, 5, 1-11.

LORMAN J.G., MAGNUSON J.J., 1978. The role of crayfish in aquatic ecosystems. Fisheries, 3(6), 8-10.

MAGNUSSON J.J., CAPELLI G.M., LORMAN J.G., STEIN R.A., 1975. Consideration of crayfish for macrophyte control. In The proceedings of a symposium on water quality management through biological control, BREZONIK P.L., FOX J.L. eds, 66-74, University of Florida, Gainesville, FL.

MASON J.C., 1975. Crayfish production in a small woodland stream. Freshwater Crayfish, 2, 449-479.

MASON J.C., 1979. Significance of egg size in freshwater crayfish, Pacifastacus leniusculus (Dana). Freshwater Crayfish, 4, 83-92.

MATTHEWS M.A., REYNOLDS J.D., 1995. A population study of the white-clawed crayfish Austropotamobius pallipes (Lereboullet) in an Irish reservoir. Journal of the Royal Irish Academy, 95B, 99-109.

MOMOT W.T., GOWING H., JONES P.D., 1978. The dynamics of crayfish and.their role in ecosystem. American Midland Naturalist, 99, 10-35.

MORRISSY N.M., 1970. Spawning of marron, Cherax tenuimanus Smith (Decapoda : Parastacidae). Western Australia. Department of Fisheries and Fauna, Western Australia Fisheries Bulletin, 10, 1-23.

O'KEEFFE C., 1986. The ecology of two populations of the freshwater crayfish Austropotamobius pallipes (Lereboullet) in Ireland. Ph. D. Thesis, Department of Zoology, University of Dublin, 1-254.

O'KEEFFE C., REYNOLDS J.D., 1983. The occurrence of crayfish diseases and their significance in Ireland. Freshwater Crayfish, 5, 299-307.

RALLO A., GARCIA-ARBERAS L., 2000. Population structure and dynamics and habitat conditions of the native crayfish Austropotamobius pallipes in a pond : A case study in Basque Country (Northern Iberian Peninsula). Bull. Fr. Pêche Piscic., 356, 1-12.

REYNOLDS J.D., 1979. Crayfish ecology in Ireland. Freshwater Crayfish, 4, 215-220.

REYNOLDS J.D., 1982. Notes on the Irish distribution of the freshwater crayfish. Bulletin of the Irish Biogeographical Society, 6, 18-24.

REYNOLDS J.D., 1989. Crayfish culture and exploitation in Ireland. In Crayfish culture in Europe, SKURDAL J., WESTMAN K., BERGAN P. I. (eds), 92-95, Directorate of Nature Management, Trondheim, Norway.

REYNOLDS J.D., CELADA J.D., CARRAL J.M., MATTHEWS M.A., 1992. Reproduction of astacid crayfish in captivity - current developments and implications for culture, with special reference to Ireland and Spain. Inv. Repr. and Dev., 22, 1-3 ; 253-266.

RHODES C.P., HOLDICH D.M., 1982. On size and sexual dimorphism in Austropotamobius pallipes (Lereboullet). The British Isles. Hydrobiologia, 89, 231-236.

RICKER W.E., 1975. Computation and interpretation of biological statistics of fish populations. Bull. Fish. Res. Board Can., 191, 382 p.

ROQUEPLO C., 1983. Etudes de populations naturelles d'écrevisses (Austropotamobius pallipes L.) dans le sud-ouest de la France. CEMAGREF, Bordeaux, $173 \mathrm{p}$. 
SCHAPERCLAUSS W., 1954. Fischkrankheiten : Krebspest. Berlin, Akademie Verlag, $708 \mathrm{p}$.

SEBER G.A.F., 1973. The estimation of animal abundance and related parameters. Eds Griffon, London, $506 \mathrm{p}$.

SHIMIZU S., GOLDMAN C., 1983. Pacifastacus leniusculus (Dana) production in the Sacramento River. Westport, Connecticut, AVI Publishing Co., 210-228.

SKURDAL J., QVENILD T., TAUGBOL T., FJELD E., 1990. A 6-year study of Thelohania contejeani parasitism of the noble crayfish, Astacus astacus L., in lake Steinfjorden, S.E. Norway. Journal of Fish Diseases, 13, 411-415.

STREMPEL K.M., 1973. Edelkrebserbrutung in zuger-glasern und Anfutterung der Krebsbrut. Sture Abrahamsson. Freshwater Crayfish, 3, 233-237.

TROSCHEL H.J., 1997. Distribution and ecology of Austropotamobius pallipes in Germany. Bull. Fr. Pêche Piscic., 347, 639-647.

UNESTAM T., 1969. Resistance to the crayfish plague in some American, Japanese and European crayfishes. Report of the Institute of Freshwater Research, Drottningholm, 49, 202-209.

UNESTAM T., 1973 a. Significance of diseases on freshwater crayfish. Freshwater Crayfish, 1, 135-150.

UNESTAM T., 1973 b. Fungal diseases of crustacea. Review of Medical and Veterinary Mycology, 8 (2), 1-20.

VERNEAUX J., GALMICHE P., JANIER S., MONNOT A., 1983. Une méthode zoologique pratique d'évaluation de la qualité des eaux courantes - Un indice biologique de qualité générale. Ann. Sci. Univ. Besançon, 4 (3), 11-21.

VEY A., VAGO C., 1973. Protozoan and fungal diseases of Austropotamobius pallipes (Lereboullet) in France. Freshwater Crayfish, 1, 165-179.

VIGNEUX E., KEITH P., NOEL P., 1993. Atlas préliminaire des crustacés décapodes d'eau douce de France. Collections Patrimoines Naturels, vol. 14, S.F.F., B.I.M.M.M.N.H.N., C.S.P., Min. Env., Paris, 55 p.

VORONIN V.N., 1971. New data on microsporidiosis of the crayfish Astacus astacus (Linné, 1758). Parazitol., 5, 181-191.

WESTMAN K., 1985. Effects of habitat modification on freshwater crayfish. In Habitat modifications and freshwater fisheries, ALABASTER J.S. ed., Butterworths, London, 245-255. 